
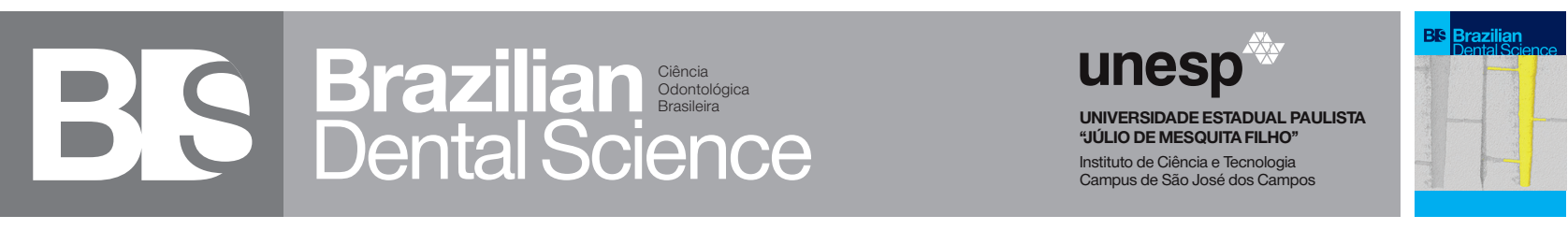

\title{
Expression of BMP II by human osteoblasts cultivated on dense or porous titanium
}

\author{
Expressão da BMP || por osteoblastos humanos cultivados sobre titânio denso ou poroso
}

Carolina Fedel GAGLIARDI ${ }^{1}$, Luana Marotta Reis de VASCONCELLOS ${ }^{1}$, Carlos Alberto Alves CAIRO², Sylvia Bicalho RABELO ${ }^{3}$, Renata Falchete do PRADO ${ }^{1}$

1 - São Paulo State University (Unesp)- Institute of Science and Technology, São José dos Campos- Department of Bioscienceand Oral Diagnosis- São José dos Campos - SP - Brasil.

2 - Division of Materials- Air and Space Institute 14 - São José dos Campos - SP - Brasil.

3 - São Paulo State University (Unesp) - Institute of Science and Technology, São José dos Campos - Department of Restorative DentistrySão José dos Campos - SP - Brasil.

\section{ABSTRACT}

Objective: Modifications of titanium have been described as an important tool improving bone repair and boneimplant contact. The aim of this research was to quantified the expression of the morphogenetic bone protein II (BMP II) produced by human cells with osteoblast differentiation, after cultured over dense or porous samples of pure titanium grade II. Material and Methods: The experimental groups were: control group, dense titanium, porosity of $33.79 \%$ and porosity of $41,79 \%(n=36)$. The samples were produced by powder metallurgy technique. Mesenquimal steam cells isolated from alveolar bone of healthy donors were stimulated to differentiate, assuming an osteoblastic phenotype, by supplemented medium and plated over the samples. After 7 and 14 days, the RNA was collected to perform reverse transcriptase polymerase chain reaction (RT-PCR) in real time. Data was analysed by t-Student and ANOVA tests. The porosity, the pore morphology and interconnection were evaluated by Scanning Electron Microscopy (SEM). Results: Total porosity (obtained after apply dimensions and density formulas) and surface porosity (SEM) presented significant differencesamong the groups. For the group of total porosity of $33.79 \%$, the superficial porosity was $32.5 \%( \pm 7.74 \%)$ and for the group of $41.79 \%$, the superficial porosity was $37.4 \%$ ( $\pm 7.95 \%)$, significantly lower. The expression of BMP II was similar in all groups. Conclusion: The present study demonstrated that powder metallurgy has a reduced ability to standardize the porosity in the samples and that the porosity does not interfere in the cellular response of BMP II production, an important inducer of osteoblastic differentiation.

\section{KEYWORDS}

Porous titanium; BMP II; Cell culture; PCR.

\section{RESUMO}

Objetivo: As modificacoes do titanio sao descritas como importantes ferramentas na melhora do reparo osseo no contato osso implante. O objetivo deste estudo foi quantificar a expressao da proteina ossea morfogenetica II (BMP II) por celulas humanas com diferenciacao osteoblastica, quando cultivadas sobre amostras de titanio puro grau II, denso ou poroso. Material e Metodos: Os grupos experimentais foram: controle, titanio denso, titanio de maior porosidade e titanio de menor porosidade, sendo que, as amostras foram confeccionadas pela tecnica da metalurgia do po. As celulas isoladas de doadores saudaveis foram plaqueadas sobre as amostras. Apos 7 e 14 dias, o RNA foi extraido das celulas. A qualidade e integridade do RNA foram analisadas qualitativamente por eletroforese e quantitativamente por espectrofotometro. O cDNA foi confeccionado e a foi utilizada tecnica de reacao em cadeia da polimerase (PCR) em tempo real. Os dados foram utilizados para quantificacao relativa, e o gene constitutivo foi a BetaActina. A morfologia e a interligacao dos poros foram comprovadas por Microscopia Eletronica de Varredura (MEV). Resultados: A porosidade superficial (MEV) teve diferenca significativa em relacao a porosidade obtida analisandose volume e massa das amostras. Para o grupo $3,79 \%$, a superficial foi de $32,5 \%( \pm 7,74 \%)$ e para o grupo $41,79 \%$ a porosidade superficial foi de $37,4 \%$ $( \pm 7,95 \%)$, significativamente menor. A expressao da BMP II foi semelhante em todos os grupos. Conclusão: Concluiu-se a metalurgia do po tem reduzida capacidade de padronizacao da porosidade das amostras por ela confeccionas e que a porosidade nao interfere na resposta celular de producao da BMP II, importante indutor de diferenciacao osteoblastica.

\section{PALAVRAS-CHAVE}

Titânio poroso; BMP II; Cultura celular; PCR. 


\section{INTRODUCTION}

$\mathrm{T}$ he topography of the titanium surface can increase osteoblast differentiation due to regulation ofgene transcription andexpression of key osteogenic factors in osseointegration. Osteoblasts, during the interaction with such surface,soffer shape changes which may be responsible for the enhanced differentiation[1]. The presence of pores accelerates the osseointegration process, significantly increasing the area of bone-implant contact, reduces the time for mechanical fixation and the period of immobilization of the rehabilitated area. Osseointegration occurs due to bone growth into the pores, phenomenon called "bone ingrowth"[2].

According to Clemowand collaborators [3] the percentage of bone growing on the porous titanium surface is inversely proportional to the square root of pore size and the shear strength properties are proportional to the extent of bone growth.

The high porosity facilitates the diffusion of body fluids, favors the migration of cells into the implant and promotes greater amount of bone tissue growth since it increases the area of contact[4], however, there must be a balance between the rate of porosity and the mechanical properties of the material.

Bone morphogenetic protein (BMP) promotes the differentiation of mesenchymal cells into osteoblasts and attracts blood vessels, providing the biological needs for healthy bone tissue. BMPII is part of the family of growth factors, initially described for its ability to induce bone formation, but also important in the morphogenetic organization of whole organism[5].

According to Kim and collaborators [6] compared surfaces of titanium treated with anodic oxidation, with different thicknesses of coating with hydroxyapatite, by the microarray technique. BMP II and Integrin family were upregulated genes in the cultures on smooth and hidroxiapatite titanium groups. According to the authors, the use of modified titanium surfaces resulted in overexpression of cell adhesion genes and regulatory genes of osteogenesis.

Modification of topography influences the expression of molecules by osteoblasts directly affecting their growth and differentiation, and BMPII, which is part of the family of growth factors, has been the subject of research studies that modify titanium. Its crucial role in osteogenesis elevates it to an important marker of the response of osteoblasts to biomaterials. Thus, the present study was designed to quantified the expression of the morphogenetic bone protein II (BMP II) produced by human cells with osteoblast differentiation, after cultured over dense or porous samples of pure titanium grade II.

\section{MATERIAL \& METHODS}

The experimental groups were: control group, dense titanium, porosity of $33.79 \%$ and porosity of $41,79 \% \quad(n=36)$. This study was approved by theEthics Committee for Experimentation on human use of Instituto of Science and Technology (n. 029/2010-PH/CEP) and was performed after signature of the consent form.

\section{Titanium samples}

Samples production was described in previous studies $[7,8]$. Briefly pure titanium grade II powder was obtained by the hydrogenation/ dehydrogenation technique (HDH). The porous titanium disks were produced adding urea (J.T.Baker. 99.6\%) to the titanium powder, as a spacer holder. Pure titanium grade II without urea allow the production of dense titanium disks $(12 \mathrm{~mm} \times 2.5 \mathrm{~mm})$ using powder metalurgy.

Four groups were delineated, as follows: a) Group 1 - control: without titanium; b) Group 2 cells in contact with dense titanium disks; c) Group 3 - cells in contact with titanium disks presenting $33.71 \%$ of porosity (titanium and urea at a mass ratio of 8:2); d) Group 4 - cells in contact with titanium disks presenting $41,71 \%$ of porosity (titanium and urea at a mass ratio of 8:3). For the entire research, 36 samples of each group were fabricated. Final $n$ for each PCR reaction was 6 , since there were biological triplicate (trhee health cell donnors) and two periods of evaluation (7 and 14 days).

First, the powder was compacted in an uniaxial press (Carver Laboratory PressWabash, UK) followed by cold isostatic pressing (Paul Weber Maschinen - u ApparaebauFuhrbachstrabeRemshaldenGrunbach). In porous samples, urea elimination was made in a vacuum oven (Marconi, Piracicaba, São Paulo, Brazil) previouly to thesinterization in a vacuum furnace (Thermal Technology, California, USA). 
The titanium density was calculated by the geometric method as previously described[9]. We used the formulas of cylinder volume $(\mathrm{Vol} .=\Pi$. r2.h) and density (Den=Mass/Volume)for all dense specimens, yielding a density compatible to that described in the literature[10]. The porous specimens were submitted to the same measurements for calculation of porosityby total volume. Specimens fabricated with titanium and urea at a mass ratio of 8:2 presented mean $33.79 \pm 1.69 \%$ and those at a ratio of $8: 3$ had mean $41.79 \pm 1.17 \%$ of porosity.
Surface porosity was evaluated in five specimens of each group using a scanning electron microscope (Carl Zeiss do Brasil and Oxford Microanalysis Group, UK) at 100x magnification, in five fields, randomly distributed on the surfaceof specimens.The "Magic Wand" selection tool,in Adobe Photoshop CS2, was used to outline all the pores in each field. Then, the Image $J$ program (NIH) was used toobtainthe percentage the pores (Figure 1).

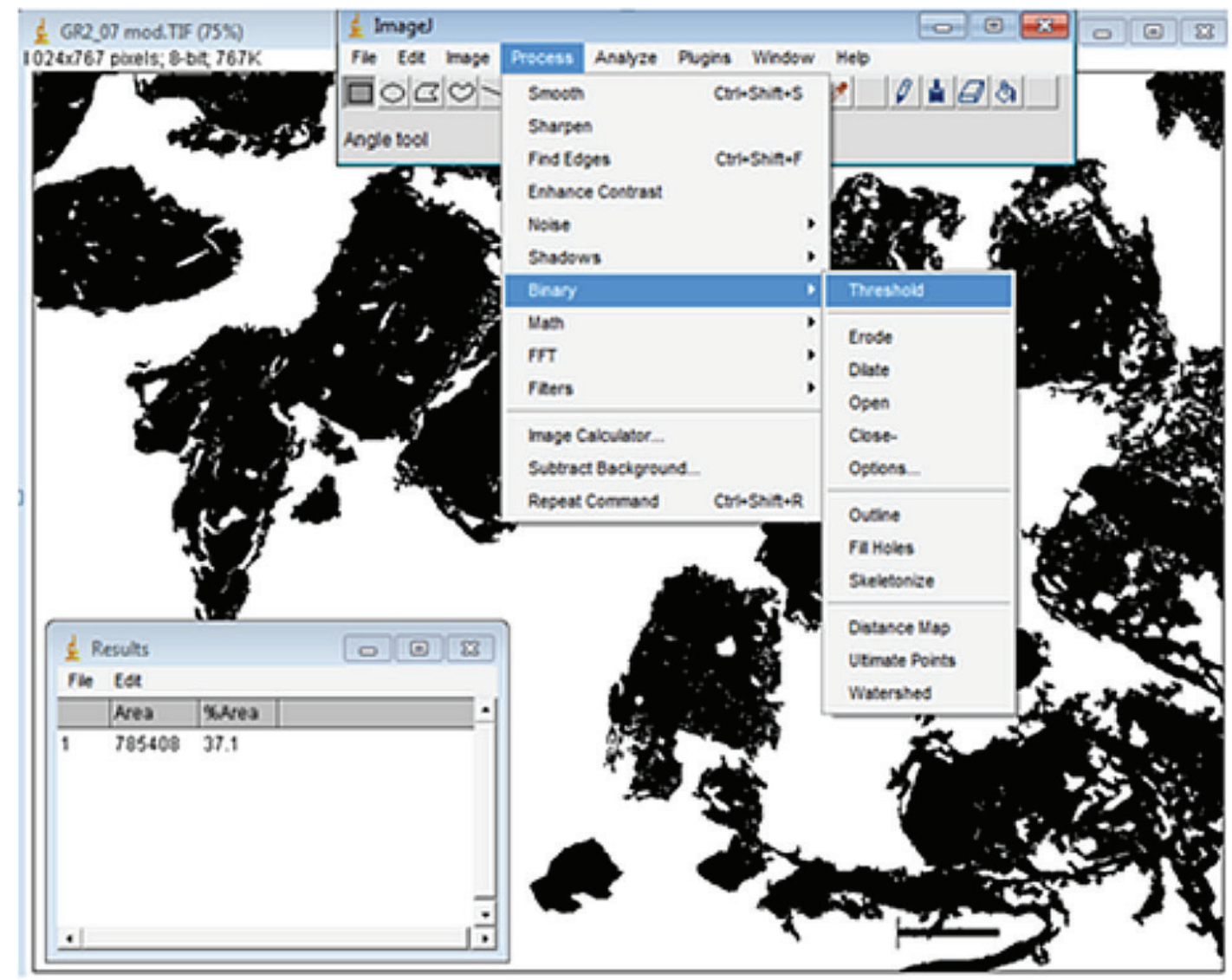

Figure 1 - Metallographic analysis. Use of the Image $\mathrm{J}$ software to obtain the percentage of pores on the surface of porous samples.

All specimens were cleaned and sterilized with 20KGY of gamma radiation by Embrarad EmpresaBrasileira de Radiações LTDA (Cotia, São Paulo, Brazil).

\section{Biological assay}

Randomly three healthy donors, regardless of gender and age, with treatment demands of tooth extraction and regularization of mandibular anterior alveolar ridge or extraction of maxillary molars with regularization of the interradicular septum were subjects in the study.

Cell isolation from bone explants were performed as previously described [8]. Briefly, 
bone fragments were kept in a supplemented total medium (MTS - $\alpha$-MEM), supplemented with $10 \%$ of fetal bovine serum (GibcoInvitrogen Corporation, New York, USA), 50 $\mu \mathrm{g} /$ $\mathrm{mL}$ of gentamicin, $0.3 \mu \mathrm{g} / \mathrm{mL}$ of fungizone, $10-7 \mathrm{M}$ of dexamethasone (Sigma-Aldrich St Louis MO, USA), $5 \mu \mathrm{g} / \mathrm{mL}$ of ascorbic acid (Mallinckrodt Chemicals, Phillipsburg, UK) and $7 \mathrm{mM}$ of betaglycerophosphate (Sigma-Aldrich St Louis MO, USA), in a CO2chamber(Ultrasafe HF 212UV Instrulab, São Paulo, Brazil).

It was performed the sequential enzyme digestion of bone fragments with type II collagenase (Gibco-Invitrogen Corporation, New York, USA). Isolated cells and explants were maintained in a humid chamber at $5 \%$ of $\mathrm{CO} 2$ and $37 \mathrm{oC}$, with medium change at every 72 hours for nearly 15 days, until cell confluence [8].

The cells were enzymatically detached using a solution of trypsin (Gibco-Invitrogen Corporation, New York, USA), EDTA1mM (Invitrogen, California, USA) and colagenase II, centrifuged, resuspended, and counted in a Neubauer chamber. Cells at passage 3-7 were plated on each group of titanium disks in 24-well polystyrene plates (Corning Incorporated, New York, USA), at a density of 20,000 cells/well[8]. In control group cells were plated on polystyrene bottom of wells,according Figure 2 .

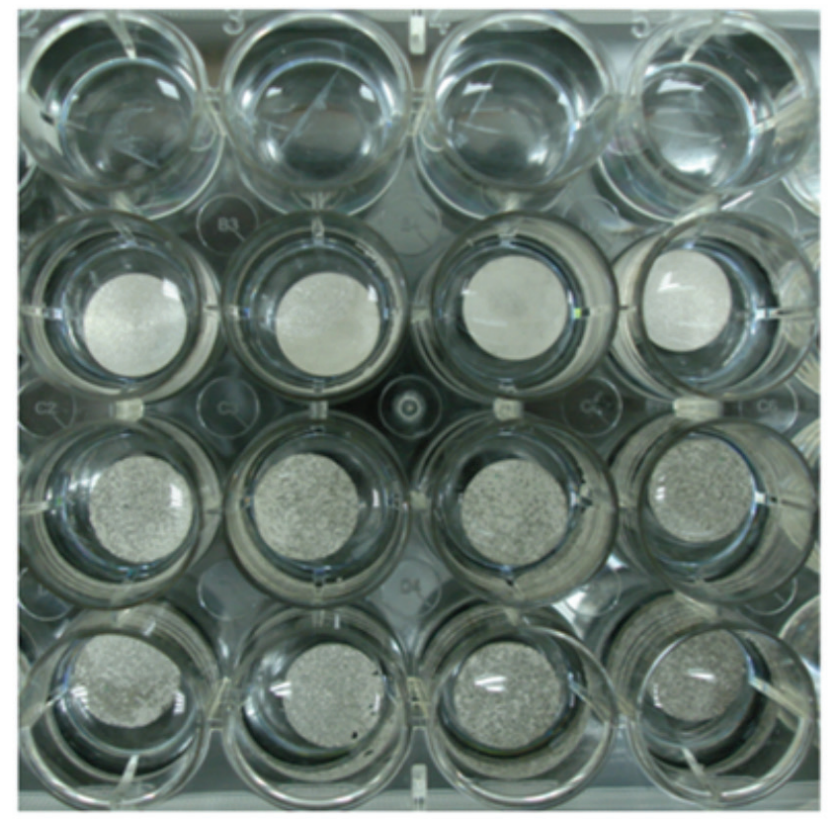

\section{Molecular analysis}

The genic expression of BMP II and the housekeeping Beta-actin was evaluated at 7 and 14 days.From each donor, many cells were obtained and six samples were used for each group and period. All tests were repeated (biological triplicate with cells from each donor). In PCR, each sample were tested three times. RNA extraction, reverse transcription and RT-PCR technique were described previously [9]. Briefly, RNA extraction was performed with Trizol Reagent (Ambion®, Life Technologies Corporation, Van Allen Way, Carlsbad, California, USA), according to the manufacturer's instructions. The concentrations and purity of RNA specimens were determined usingNano Drop 2000 (Thermo Fisher Scientific Inc. - Wilmington, DE 19810, USA). The cDNA synthesis was performed by reverse transcription reactions following the manufacturer's instructions of the commercial kit SuperScript III, FirstStrand Synthesis Supermix (InvitrogenLife Technologies Corporation-Van Allen Way, Carlsbad, California, USA).The RT-PCR conditions for each gene were standardized with efficiency and melting curves, always following instructions provided by the manufacturer of the system Platinum SYBR Green qPCR SuperMix-UDG (InvitrogenLife Technologies Corporation-Van Allen Way, Carlsbad, California, USA).

The cDNA was used for real time PCR with the detection system Line Gene K Real Time PCR Detection System(Bioer Technology Hitech Binjiang District, Hangzhou, P.R. China), using SYBER Green and specific Primers. Betaactin and BMP II primers characteristics are presented in Figure 3. The RT-PCR reactions were performed in duplicate at the experiment day and repeated in biological triplicate.

Figure 2 - Plate layout containing the samples of each group. 


\begin{tabular}{|c|c|c|c|c|c|c|}
\hline \multicolumn{4}{|c|}{ product length $=206$} & \multicolumn{2}{|c|}{ Length StartStop Tm } & \multirow{2}{*}{ GC\% $\begin{array}{l}\text { Self Self } 3^{\circ} \\
\text { complementarity complementarity }\end{array}$} \\
\hline Forward primer & 1 & AAACTGGAACGGTGAAGGTG & 20 & & & \\
\hline Texplate & 1356 & $\ldots \ldots \ldots \ldots \ldots \ldots \ldots$ & 1375 & 20 & 1356137552.5450 .003 .00 & 0.00 \\
\hline $\begin{array}{l}\text { Reverse primer } \\
\text { Template }\end{array}$ & $\begin{array}{l}1 \\
1561\end{array}$ & $\begin{array}{l}\text { GTGGACTTGGGAGAGGACTG } \\
\cdots \ldots \ldots \ldots \ldots \ldots \ldots\end{array}$ & $\begin{array}{l}20 \\
1542\end{array}$ & 20 & 1561154253.5560 .002 .00 & 1.00 \\
\hline
\end{tabular}

\begin{tabular}{|c|c|c|c|c|c|c|}
\hline product length & \multicolumn{3}{|l|}{$=197$} & \multicolumn{2}{|c|}{ Length Start Stop Tm } & GC\% $\begin{array}{l}\text { Self } \\
\text { complementarity complementarity }\end{array}$ \\
\hline Forward primer & 1 & TCAAGCCAAACACAAACACC & 20 & & & \\
\hline Template & 1631 & $\cdots \cdots \cdots \cdots \cdots \cdots \cdots$ & 1650 & 20 & 1631165051.9945 .002 .00 & 2.00 \\
\hline primer & 1 & ACGTCTGAACAATGGCATGA & 20 & 20 & 1827180852.0245 .005 .00 & 2.00 \\
\hline
\end{tabular}

https://www.ncbi.nlm.nih.gov/tools/primer-blast/

Figure 3 - Image illustrating the results of Pubmed validation of primers design. In figure it is possible to detect product lenght, melting temperature, self complementarity, and GC\% of each oligo.

After the RT-PCR reactions, the Ctvalues of specimens were used for relative quantification by the comparative method of $\Delta \Delta \mathrm{Ct}[11]$, in which the genic expression occurs in relation to the constitutive gene and is then normalized by its expression in the control group.

\section{Statistical analysis}

Student $t$ test was used to proceed statistical comparison of the porosity obtained by the geometric method and by metallography analysis. Gene expression of the BMP II was compared using ANOVA one way (porosity). Significant level of $5 \%$ was adopted.

\section{RESULTS}

Scanning electron microscopy (SEM) proved the interconnection of pores (Figure4). Pores of varied sizes were observed, on the surface of porous samples. The surface porosity had a significant difference in comparison to that obtained in geometric analysis. For the group $33.79 \%$, there was no differences. The surface porosity was $32.5 \%$ ( $\pm 7.74 \%)$. However, for the group of $41.79 \%$, the surface porosity percentage was $37.4 \%$ ( $\pm 7.95 \%)$, significantly lower.

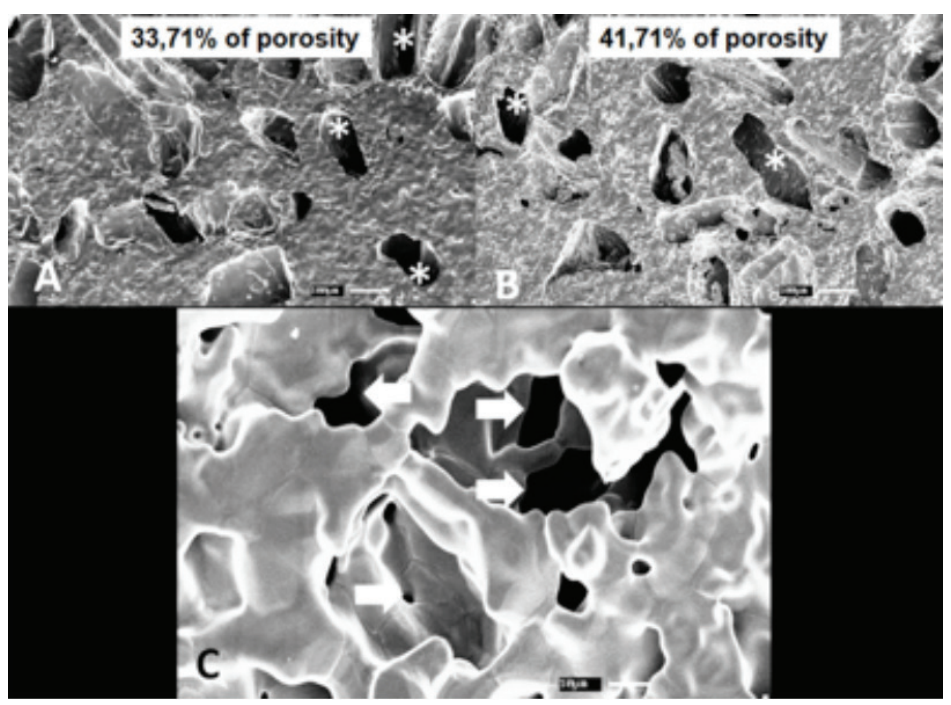

Figure 4 - SEM images of porous samples. Surface large pores are marked $\left.{ }^{*}\right)$. A)Sample from the group 33,71\% of porosity. B) Sample from the group $41,71 \%$ of porosity. C) Zoom of large superficial pores with their deep walls presenting channels conecting surface and intern pores. The opening of these channels are marked $(\rightarrow)$ 
Relative quantification of BMP II expression is presented in Figure 5. At 7 days of culture, the analysis of variance by ANOVA showed no significant difference between BMP II expression by the cells in contact with each type of sample, with $\mathrm{p}=0,2979$.At 14 days, there was also no statistical significance in the BMP II expression in each group, with $\mathrm{p}=0.7669$. At 14 days, group Porosity of $41,79 \%$ presented high values of BMP II, comparable to control group.

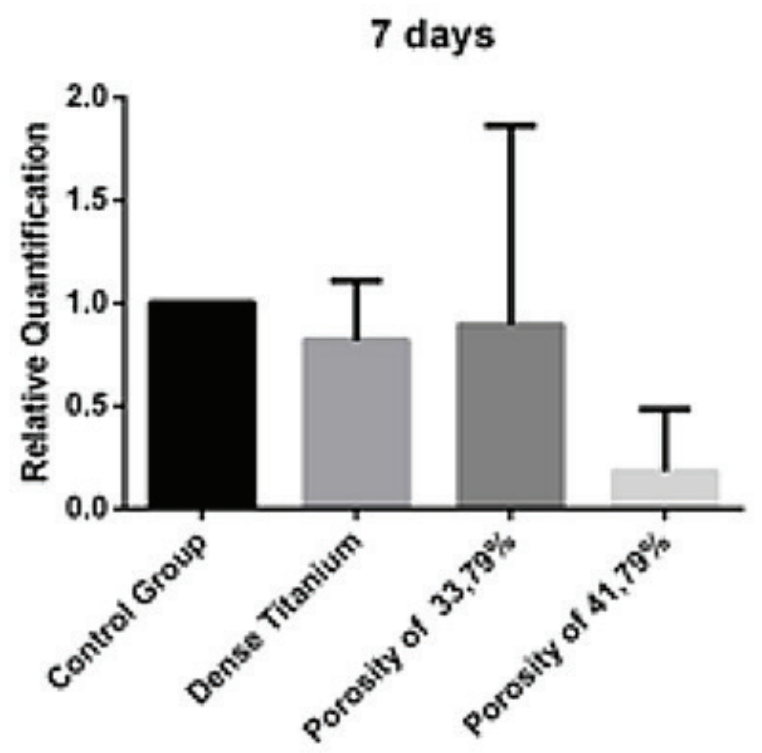

14 days

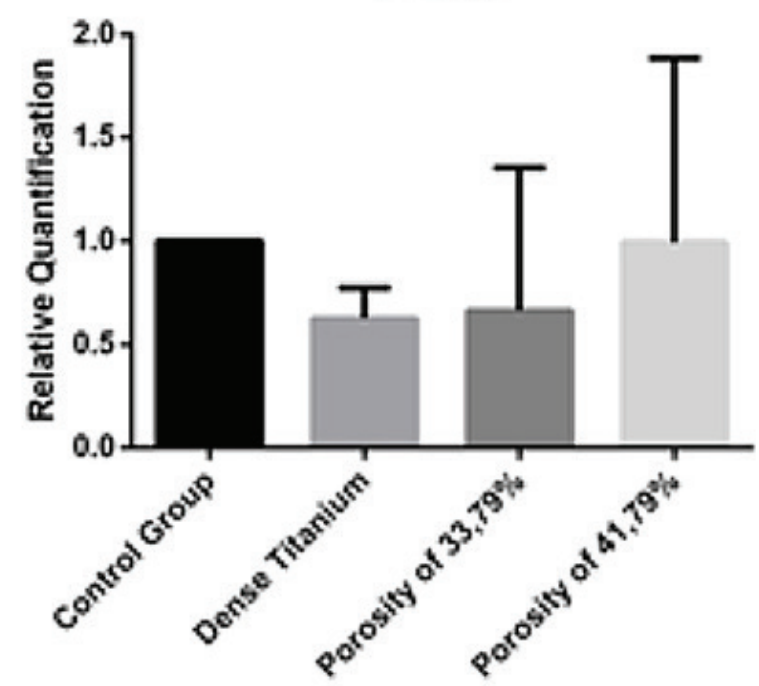

Figure 5 - Effects of porosity in the RNA expression of BMP II. There was no difference among groups.

\section{DISCUSSION}

The powder metallurgy allowed the fabrication of a porous surface, with interconnected pores, of satisfactory sizes. Porous samples are investigated to improve bone growth and reduce the difference of the elastic modulus between bone and metal surface, as well as prevent aseptic implant loosening and increase its longterm stability. In general, the two percentages of porosity evaluated in the present study had similar performance in the applied tests. The distance of 8 percentage points (geometric analysis) and 5 percentage points (metallographic analysis) did not modify the properties of the two groups of porous titanium samples made by powder metallurgy. An important fact is high standard deviation of the surface porosity that was found in the metallographic analysis,since cells interact with the surface of the sample. Powder metallurgy does not allowed ancontrol of the surface urea grains' arrangement and consequently, porosity in the sample as a whole, constituting a technical limitation.

Bone morphogenetic protein II (BMP II) is a key regulatory protein in osteogenic pathways. The material used in implantsmust have the capacity to reproduce similar properties to those found in biological systems, thereby reducing the healing time and achieving early osseointegration[12].

The application of BMP II in implant surfaces arises as an applied idea, which is still a major challenge for clinical application. A new method has been proposed to synthesize a BMP II functionalized silane film and apply it to titanium surfaces. It has been observed that the BMP II modified surfaces in dental implants improved mineralization. Through silanization, BMP II protein can enhance proliferation and increase expression of alkaline phosphatase, which detects early osteogenesis and mineralization. The results suggest that a biologically active surface can be designed to accelerate mineralization by osteoprogenitor cells, but this should be tested in vivo to confirm the results[13]. However, in the present study,the topography alone did not present the ability of alter the cellular gene expression in vitro.

Data from gene expression showed that, although not statistically significant, it was higher 
in the control group, whose cells were cultured in the bottom of the well of the culture plate. Plastic represents both a smoother surface and is chemically different from titanium, as well as being the standard environment for cell culture. The expression of BMP II (denoting higher differentiation induced by topography) was expected from the cells grown on porous surfaces, but this was not observed. The percentage of porosity generated a minimal difference in the expression of BMP II between the porous groups at 7 , but at 14 days, a more pronounced difference was observed, but the high standard deviation was noted. We suggest the need to increase the number of samples per group to try to minimize this limitation.

According to Rosa and collaborators[14] there is delay in the differentiation of osteoblasts in the porous surface. However, at 7th day the lower porosity group had BMP expression similar to the dense titanium group and at the fourteenth day, the group with the highest porosity had the most pronounced expression. Denoting a change in the phase of cell differentiation with the course of culture time.

\section{CONCLUSION}

The present study demonstrated that the powder metallurgy has a reduced ability to standardize the porosity of the samples and that porosity does not interfere in the cellular response of BMP II production, an important inducer of osteoblastic differentiation.

\section{ACKNOWLEDGMENT}

The authors thank to FAPESP for the scholarship process number 2016/05343-1.

\section{REFERENCES}

1. Masaki C, Schneider GB, Zaharias R, Seabold D, Stanford C. Effects of implant surface microtopography on osteoblast gene expression. Clin Oral Implants Res. 2005;16:650-656. doi:10.1111/.1600-0501.2005.01170.x
2. Deporter DA, Watson PA, Pilliar RM, Chipman ML, Valiquette N. A histological comparison in the dog of porous-coated vs. threaded dental implants. J Dent Res. 1990;69: 1138-45. doi:10.1177/00220345900690050401

3. Clemow AJT, Weinstein AM, Klawitter JJ, Koeneman J, Anderson J. Interface mechanics of porous titanium implants. J Biomed Mater Res. 1981;15:73-82. doi:10.1002/jbm.820150111

4. Vasconcellos LMR, Oliveira MV V, Graca MLA, Vasconcellos LGO, Cairo CAA, Carvalho YR. Design of dental implants, influence on the osteogenesis and fixation. J Mater Sci Mater Med. 2008;19:2851-2857. doi:10.1007/s10856-008$3421-6$

5. Hughes FJ, Turner W, Belibasakis G, Martuscelli G. Effects of growth factors and cytokines on osteoblast differentiation. Periodontol 2000.2006;41:48-72. doi:10.1111/.1600-0757.2006.00161.x

6. Kim C-S, Sohn S-H, Jeon S-K, Kim K-N, Ryu J-J,Kim M-K. Effect of various implant coatings on biological responses in MG63 using cDNA microarray. J Oral Rehabil. 2006;33:368-79. doi:10.1111/.j365-2842.2005.01553.x

7. de Andrade DP, de Vasconcellos LMR, Carvalho ICS, Forte LF de BP, de Souza Santos EL, Prado RF do, etal. Titanium-35niobium alloy as a potential material for biomedical implants: In vitro study. Mater Sci Eng C Mater Biol Appl. 2015;56:538-44. doi:10.1016/.j.msec.2015.07.026

8. do Prado RF, Rabêlo SB, de Andrade DP, Nascimento RD, Henriques VAR, Carvalho YR, et al. Porous titanium and Ti-35Nb alloy: effects on gene expression of osteoblastic cells derived from human alveolar bone. J Mater Sci Mater Med. 2015;26. doi:10.1007/s10856-015-5594-0

9. Prado RF do, de Oliveira FS, Nascimento RD, de Vasconcellos LMR, Carvalho YR, Cairo CAA. Osteoblast response to porous titanium and biomimetic surface: In vitro analysis. Mater Sci Eng C Mater Biol Appl. 2015;52: 194-203. doi:10.1016/..msec.2015.03.028

10. McQueen RG, Jamieson JC, Marsh SP.Shock-wave compression and x-ray studies of titanium dioxide. Science. 1967;155: 1401-4. doi:10.1126/ science.155.3768.1401

11. Livak KJ, Schmittgen TD. Analysis of Relative Gene Expression Data Using Real-Time Quantitative PCR and the 2Å $\triangle \Delta C T$ Method. Methods. 2001;25: 402-408. doi:10.1006/meth.2001.1262

12. De Vasconcellos LMR, Oliveira FN, De Oliveira Leite D, De Vasconcellos LGO, Do Prado RF, Ramos CJ, et al. Novel production method of porous surface Ti samples for biomedical application. J Mater Sci Mater Med. 2012;23. doi:10.1007/s10856-011-4515-0

13. Teng F-Y,Chen W-C, Wang Y-L, Hung C-C, Tseng C-C. Effects of Osseointegration by Bone Morphogenetic Protein-2 on Titanium Implants In Vitro and In Vivo. Bioinorg Chem Appl. 2016;2016:3837679. doi:10.1155/2016/3837679

14. Rosa AL, Crippa GE, de Oliveira PT, Taba M, Lefebvre L-P,Beloti MM. Human alveolar bone cell proliferation, expression of osteoblastic phenotype, and matrix mineralization on porous titanium produced by powder metallurgy. Clin Oral Implants Res. 2009;20:472-81. doi:10.1111/.1.1600-0501.2008.01662.x

\author{
Renata Falchete do Prado \\ (Corresponding address) \\ Institute of Science and Technology \\ Department of Bioscience and Oral Diagnosis \\ Av. Eng. Francisco José Longo, 777, São José dos Campos, SP - Brasil. \\ renatafalchete@hotmail.com
}

Date submitted: 2018 Apr 16 Accept submission: 2018 Jun 07 